\title{
The effect of lead on the fragility of the red cell incubated in vitro
}

\author{
H. A. WALDRON
}

From the Medical Department, Vauxhall Motors Ltd., Luton

SYNOPSIS Osmotic and mechanical fragilities of the red cell were determined before and after incubation with varying amounts of lead in vitro.

Lead caused a very marked increase in the resistance of the red cells to hypotonic saline solutions, although it did not increase the mechanical fragility index of the cells after incubation significantly more than in the control samples of blood which were incubated without lead.

Observations by Aub, Fairhall, Minot, and Reznikoff (1926) indicated that when lead was added to red cells in vitro they became more resistant to haemolysis in hypotonic saline solutions, a finding subsequently confirmed by Pearse (1926) and by Clarkson and Kench (1958b). As a result of their investigations, Aub and his colleagues suggested that lead altered the red cell membrane in such a way as to render it more susceptible to trauma during passage through the capillaries, thus causing the anaemia frequently associated with lead poisoning. A recent study, however (de Kretser and Waldron, 1963), has failed to substantiate this hypothesis.

It was felt that it would be of some interest to study the effect of lead on the osmotic and mechanical fragilities of the red cell after sterile incubation with lead in vitro for 24 hours.

\section{METHODS AND MATERIALS}

Blood was collected by venepuncture into sterile heparin bottles from male volunteers who had had no industrial exposure to lead, nor any clinical or laboratory evidence of haematological disorders, past or present.

The osmotic fragility tests were performed by the method of Dacie (1956) using the buffered saline solution of Parpart, Lorenz, Parpart, Gregg, and Chase (1947). The results were expressed in the form of haemolytic increments(Suess, Limentani, Damashek, and Dolloff, 1948).

The mechanical fragility index was determined as described by de Kretser and Waldron (1963).

Volumes of a standard lead acetate solution (100 $\mu \mathrm{g}$. lead $/ \mathrm{ml}$.) were added to tubes sufficient to give final concentrations of 10 and $20 \mu \mathrm{g}$. lead $/ \mathrm{ml}$. blood. The tubes were dried and sterilized by autoclaving. Whole blood, $3 \mathrm{ml}$., was added to the dried tubes and mixed by gentle inversion before incubating for 24 hours at $37^{\circ} \mathrm{C}$. Then $3 \mathrm{ml}$. of whole blood was incubated in sterile tubes without lead, as a control, and osmotic and mechanical Received for publication 16 December 1963. fragilities were determined at the end of the incubation time. The results obtained were compared with those recorded before incubation.

\section{RESULTS}

The results of the incubated osmotic fragility tests are represented in Figures 1 and 2. Figures are expressed as the mean of the results in each group, group I being comprised of samples of blood incubated with $10 \mu \mathrm{g}$. lead $/ \mathrm{ml}$., and group II, those incubated with $20 \mu \mathrm{g}$. lead $/ \mathrm{ml}$. Twenty results were obtained from each group.

From the figures it will be noted that incubating whole blood without lead causes the cells to become more fragile, as one would expect, but the addition of lead causes a marked resistance to hypotonic saline solutions, a feature particularly noticeable in group II.

The results of the mechanical fragility experiments are given in Table I. It will be noted that incubation causes the mechanical fragility index of the red cells to increase appreciably, a finding previously reported by Bakker-v Aardenne, Verloop, and van Boetzelaer (1957). The mechanical fragility index of the blood incubated with lead was raised only slightly above that of the controls. This finding was consistent in both groups.

\section{TABLE I}

MECHANICAL FRAGILITY INDEX OF RED CELLS BEFORE AND AFTER INCUBATION WITH AND WITHOUT LEAD ADDED IN VITRO

\begin{tabular}{lccc} 
& $\begin{array}{l}\text { Before } \\
\text { Incubation }\end{array}$ & $\begin{array}{c}\text { Control after } \\
\text { Incubation }\end{array}$ & $\begin{array}{c}\text { Test after } \\
\text { Incubation }\end{array}$ \\
\hline Group I & 9.9 & 21.9 & $24 \cdot 0$ \\
Group II & $9 \cdot 1$ & 23.1 & 27.3 \\
Whole group & 9.5 & 22.5 & 25.6
\end{tabular}




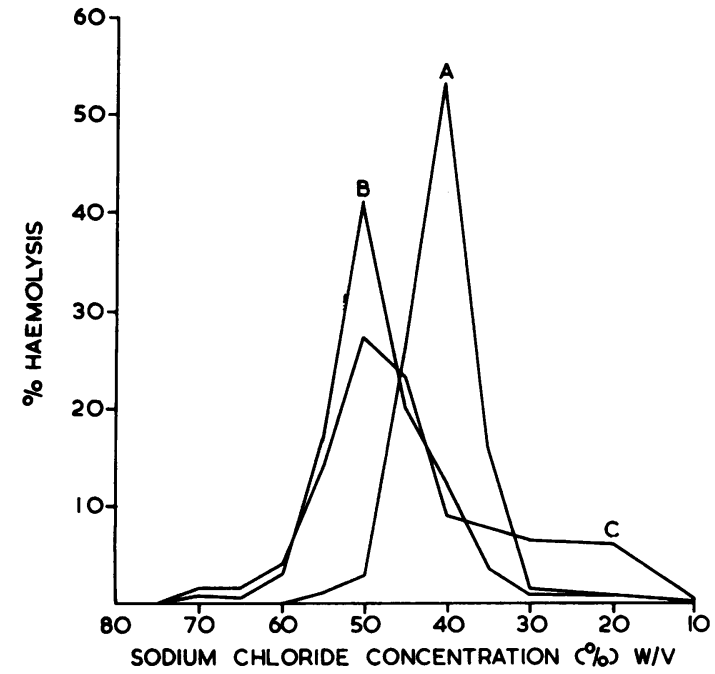

FIG. 1. Haemolytic increment curves, $A$, before incubation, $B$, after incubation, and $C$, after incubation with lead $(10 \mu \mathrm{g} . / \mathrm{ml}$.$) added in vitro.$

\section{DISCUSSION}

As a result of their studies on the effect of lead on red cells in vitro, Aub et al. (1926) postulated that precipitation of lead tri-phosphate took place on the red cell membrane by the reaction of lead salt with inorganic phosphate groups. As a result of this reaction hydrochloric acid was released and the points of localized acidity which were created were responsible for the increased fragility of the red cell. The increase in mechanical fragility of the cell would give rise, in vivo, to the anaemia associated with lead poisoning.

Detailed kinetic studies by Clarkson and Kench (1958a), however, suggested a quite different mechanism for lead uptake. These authors considered that a peptized lead phosphate sol was first formed which then reacted on the cell membrane to form a precipitate of lead phosphate. Clarkson and Kench (1958b) found that the addition of lead to red cells in vitro caused a marked increase in resistance to haemolysis in hypotonic saline solutions. They concluded, however, that, in vivo, plasma lead will cause only minimal changes in the fragility of the circulating red cell.

The findings reported in the present paper indicate that incubating red cells with lead in vitro causes a marked decrease in osmotic fragility. It is known that lead can affect the permeability of the red cell membrane (Prankerd, 1961) and it may be possible to explain the increased resistance to hypotonic saline solutions in these terms. More work

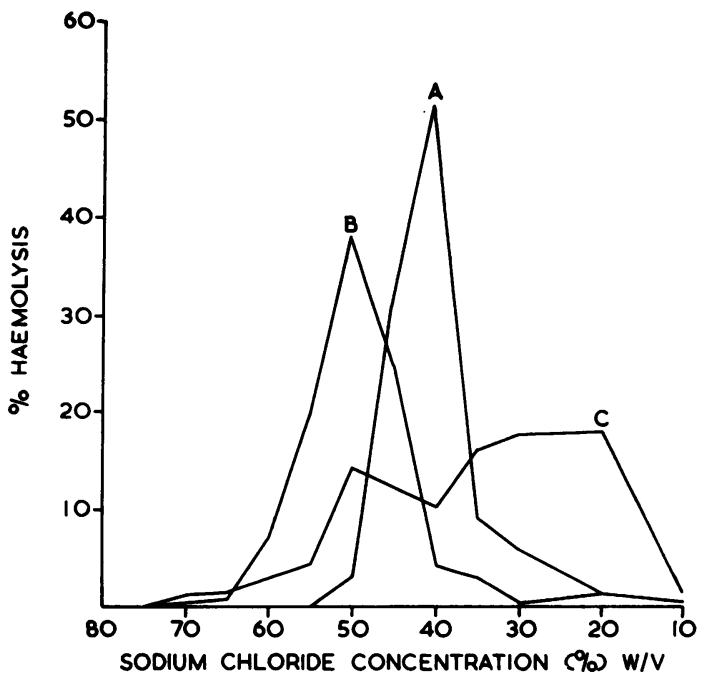

FIG. 2. Haemolytic increment curves, $A$, before incubation, $B$, after incubation, and $C$, after incubation with lead $(20 \mu \mathrm{g} . / \mathrm{ml}$.) added in vitro.

would be necessary, however, before this could be stated with any degree of certainty.

The experiments reported here on the mechanical fragility of the erythrocyte suggest that lead causes only minimal changes in the mechanical fragility of $\frac{\mathbb{Q}}{2}$ the red cell. Although incubation with lead $\mathrm{did} \stackrel{\mathrm{F}}{\mathrm{f}}$ increase the mechanical fragility index of the cello slightly more than in the control groups, the difference between the sets of results was by not means great. This finding is in keeping with that of de Kretser and Waldron (1963), who found that the? mechanical fragility index in a group of lead workers was not greater than that of a control group of workers with no industrial exposure to lead. It윽 seems likely, therefore, that an increase in the mechanical fragility index of the red cell is not a 5 major factor in the production of lead anaemia.

My thanks are due to Dr. A. R. Thompson and the Management of Vauxhall Motors for permission to publish this paper.

\section{REFERENCES}

Aub, J. C., Fairhall, L. T., Minot, A. S., and Reznikoff, P. (1926). Lead Poisoning. Williams \& Wilkins, Baltimore.

Bakker-v Aardenne, W. I. T., Verloop, M. C., and van Boetzelaer

G. C. D. (1957). Trans. 6th Congr. europ. Soc. Haematol., Copenhagen, pt. 2. p. 695. Karger, Basel.

Clarkson, T. W., and Kench, J. E. (1958a). Biochem. J., 69, 432. ,--1958 b). Brit. J. industr. Med., 15, 115.

Dacie, J. V. (1956). Practical Haematology, p. 98. Churchill, London. de Kretser, A. J., and Waldron, H. A. (1963). Brit. J. industr. Med., 20, 316.

Parpart, A. K., Lorenz, P. H., Parpart, E. R., Gregg, J. R., and Chase, A. M. (1947). J. clin. Invest., 26, 636.

Pearse, H. E. (1926). Arch. intern. Med., 37, 715.

Prankerd, T. A. J. (1961). The Red Cell, p. 55. Blackwell, Oxford.

Suess, J., Limentani, D., Damashek, W., and Dolloff, M. J. (1948). Blood, 3, 1290

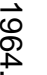

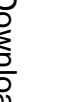

